\title{
Metabolic Fate of Menaquinone-4 in Dogs (II): Absorption, Distribution, Metabolism and Excretion after Repeated Oral Administration
}

\author{
Yoshihisa Sano, Kyoichi Tadano, Kiyomi KikUchi, Kazuhiro KaneKo \\ Teruaki Yuzuriha, Tomonori KimURA* and Yoshihiko Murayama* \\ Tsukuba Research Laboratories, Eisai Co., Ltd., 5-1-3, Tokodai, Tsukuba-shi, Ibaraki 300-26; \\ *Tsukuba Laboratory, Nemoto \& Co., Ltd., 6136-4, Nakamaru, Ohnogoh, Mitsukaido-shi, Ibaraki 300-25, Japan
}

\begin{abstract}
Summary: $\quad\left[{ }^{14} \mathrm{C}\right]$ menaquinone -4 , a therapeutic agent for osteoporosis, was administered orally to male dogs at a dose of $4 \mathrm{mg} / \mathrm{kg}$ once a day for seven days, and the absorption, distribution, metabolism and excretion were investigated.

1. The mean plasma concentration of radioactivity reached a maximum level at 1.5 hours after the 1 st administration and thereafter decreased slowly. The concentrations at 1.5, 4 and 24 hours after each dose increased daily and approached a steady state by the 7th (final) dose, whereas constant plasma concentrations of unchanged menaquinone -4 were observed during repeated administration. The concentrations of radioactivity in erythrocytes increased during repeated administration and had not reached a steady state by the 7 th dose.

2. The concentrations of radioactivity in the bile, liver, adipose, gall bladder and spleen at 1.5 hours after the final dose were 1.0, 0.9, 10.1, 0.6 and 1.2 fold, respectively, and were greater than those after a single dose. Radioactivity was highly accumulated in adipose tissues. In bone tissues, the target organ of the drug, the marrow and cancellous tissue of thighbone and the marrow of ribs showed higher concentrations than plasma levels at 1.5 hours, and were 3.7, 2.6 and 2.7 fold higher, respectively, than those after a single dose.

3. In urine and feces, 2.4 and $84.0 \%$ of the dosed radioactivity was excreted within 168 hours after the 7 th dose, respectively. Unrecovered radioactivity was present in the adipose and other tissues at 168 hours.

4. The metabolic profile of $\left[{ }^{14} \mathrm{C}\right]$ menaquinone -4 after repeated administration was similar to that after single administration. The unchanged menaquinone- 4 was the major form present in the plasma, liver, kidney, spleen, adrenal, adipose and cancellous tissue of thighbone at 1.5 hours and in feces excreted within 24 hours after the 7th dose. In the adipose and cancellous tissue of thighbone, the unchanged menaquinone -4 was the major form up to 168 hours, while the relative amounts of metabolites increased by 24 hours in the other tissues.

5. The levels of radioactivity in the marrow and cancellous tissue of thighbone and the marrow of ribs increased with repeated administration, and in the end were comparable to the pharmacologically effective concentrations of menaquinone-4 $\left(10^{-6}-10^{-5} \mathrm{M}\right)$ observed in in vitro studies on bone formation. It is, therefore, expected that repeated administration of menaquinone -4 may contribute to the pharmacological action of the drug as a treatment for osteoporosis.
\end{abstract}

Key words: Menaquinone-4, Vitamin K, Oral, Absorption, Distribution, Metabolism, Excretion, Dogs, Bone, $\gamma$-carboxylase, Osteoporosis

\section{Introduction}

Menaquinone -4 (vitamin $\mathrm{K}_{2}$ ) is a cofactor in the carboxylation of specific glutamyl residues of proteins and is now supplied in a soft-capsule formulation as a medication for the treatment of human osteoporosis ${ }^{1)}$. Its pharmacological activity has been demonstrated in human osteoblasts in vitro ${ }^{2)}$ and also in ovariectomized rats, the latter serving as an in vivo model for human osteoporosis ${ }^{3}$.
The pharmacokinetic profile of menaquinone- 4 in rodents has already been reported ${ }^{4-7)}$, while that in dogs was recently investigated using a soft-capsule formulation following the establishment of a simple and sensitive HPLC assay method for menaquinone- 4 in plasma ${ }^{8)}$. The metabolic fate of menaquinone- 4 , including its distribution into bone tissues, the target of the drug, have also been reported in normal and ovariectomized rats $\left.{ }^{9}, 10\right)$, and $\operatorname{dogs}^{11}$.

Menaquinone- 4 will normally be prescribed for an ex- 
tended period of time as a therapeutic agent for osteoporosis. Thus, in this report, the absorption, distribution, metabolism and excretion of menaquinone- 4 were investigated in male dogs during and after repeated oral administration of $\left[{ }^{14} \mathrm{C}\right]$ menaquinone-4. The effects of repeated dosing on the metabolic fate of the drug were examined in particular detail.

\section{Materials and Methods}

\section{Materials}

$\left.{ }^{[14} \mathrm{C}\right]$ menaquinone-4 (Fig. 1) was synthesized from ethyl $\left[3^{-14} \mathrm{C}\right]$ acetoacetate by Amersham (Buckinghamshire, UK) according to a procedure previously described $^{12)}$. The specific radioactivity was $2.83 \mathrm{MBq} /$ $\mathrm{mg}$ and the radiochemical purity was $99 \%$ or more based upon HPLC analysis. Unlabeled menaquinone-4 was synthesized by Eisai Chemical Co., Ltd. (Ibaraki, Japan), and added to the radiolabeled compound to obtain a specific activity of $0.465 \mathrm{MBq} / \mathrm{mg}$ prior to preparation of the formulation. Propyleneglycol dicaprylate (Cefsol 228 $8^{\circledR}$ ) and glycerol monooleate (MGOL-70 were purchased from Nikko Chemicals Co., Ltd. (Tokyo, Japan). Reagents for buffer solutions were of analytical grade and other solvents were of HPLC grade (Wako Pure Chemical Industries, Ltd., Osaka, Japan).

\section{Animals}

Ten male beagle dogs were obtained from Oriental Bioservice Kanto, Inc. (Ibaraki, Japan) and used at 15 months of age. Their body weights ranged 8.0 to $9.8 \mathrm{~kg}$. All animals were acclimatized for 2 month to a room temperature of $23 \pm 2^{\circ} \mathrm{C}$ and a relative humidity of $50 \pm 10 \%$. They were fed $220 \mathrm{~g}$ of commercial food (DS, Oriental Yeast Co., Ltd., Tokyo, Japan) daily and given water ad libitum throughout the study. On dosing days, the food was given restrictedly for 1 hour before drug administration.

\section{Preparation of $\left[{ }^{14} \mathrm{C}\right]$ menaquinone-4 dosing so- lution}

An oily liquid formulation was prepared according to the description for a soft-capsule formulation outlined in a previous report ${ }^{8)} \cdot\left[{ }^{14} \mathrm{C}\right]$ menaquinone-4 was dissolved in Cefsol 228 $/$ MGOL-70 $(40: 55, \mathrm{w} / \mathrm{w})$ at a concentration of $4 \mathrm{mg} / 80 \mathrm{mg}$ with heating at $60^{\circ} \mathrm{C}$. This dosing

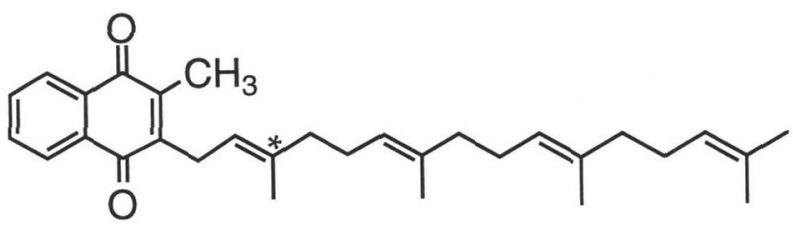

Fig. 1 Chemical structure of $\left[{ }^{14} \mathrm{C}\right]$ menaquinone- 4 $\left({ }^{*}:\left[{ }^{14} \mathrm{C}\right]\right.$ labeled position) solution was divided into seven amber glass tubes and stored at $-20^{\circ} \mathrm{C}$ until use. The radiochemical purity was confirmed on both the first and last administration days using HPLC analysis.

\section{Administration}

$\left[{ }^{14} \mathrm{C}\right]$ menaquinone- 4 was orally administered at a dose of $4 \mathrm{mg} / \mathrm{kg}$ once a day for seven days. Dosing solutions were thawed daily by heating, weighed and placed in a gelatin capsule each day. Thirty $\mathrm{ml}$ of water were given immediately after dosing.

\section{Measurement of radioactivity}

The radioactivity in samples was measured with a liquid scintillation counter (LSC-3500; Aloka, Tokyo, Japan). Quenching was corrected automatically using an external standard.

\section{Determination of blood, plasma and erythro-} cyte concentrations of radioactivity

After the 1st, 3rd, 5th and 7th dosings, $1.5 \mathrm{ml}$ of blood samples were withdrawn from 4 male dogs via the cephalic vein at specified times up to 24 hours to determine the time-concentration profiles. Additional blood sampling was carried out at 1.5, 4 and 24 hours after the 2 nd, 4 th and 6th dosings. After a $50 \mu l$ aliquot of blood sample was collected, the plasma was separated from erythrocytes by centrifugation of the residual blood sample and a $50 \mu l$ aliquot of each sample was obtained to measure the radioactivity. Two hundred $\mu l$ aliquots of plasma up to 24 hours after the 1st, 3rd, 5th and 7th dosings were divided into amber tubes and stored at $-20^{\circ} \mathrm{C}$ until the measurement of unchanged menaquinone-4 levels.

Fifty $\mu l$ aliquots of blood and erythrocytes were solubilized with $1.5 \mathrm{~m} l$ Soluene--350 ${ }^{\circledR}$ (Packard, Groningen, Netherlands)/isopropyl alcohol $(1: 1, \mathrm{v} / \mathrm{v})$ before adding $30 \% \mathrm{H}_{2} \mathrm{O}_{2}$ solution to the solubilized samples for decolorization. Plasma samples $(50 \mu l)$ were solubilized with $1.5 \mathrm{ml}$ Soluene-350®/isopropyl alcohol (1: $1, \mathrm{v} / \mathrm{v})$. Twelve $\mathrm{m} l$ of scintillation fluid comprising Insta-gel ${ }^{\circledast}$ (Packard) $/ 0.5 \mathrm{~N} \mathrm{HCl}(9: 1, \mathrm{v} / \mathrm{v})$ were then added to the solubilized samples.

\section{Determination of menaquinone-4 in plasma}

Unchanged menaquinone- 4 was measured as described in previous reports ${ }^{8,11}$. Briefly, after adding internal standard ( $5 \mu \mathrm{g}$ of menaquinone- 6 ; prepared by Eisai Co., Ltd.) and $1 \mathrm{ml}$ of $0.2 \mathrm{M}$ phosphate buffer ( $\mathrm{pH}$ 8) to $200 \mu l$ plasma samples, menaquinone- 4 was extracted twice with $4 \mathrm{ml}$ of isopropyl alcohol / $\mathrm{n}$-hexane $(8: 92)$. The organic layer was then evaporated to dryness and the residue was dissolved in $200 \mu \mathrm{l}$ of EtOH/ $\mathrm{MeOH} / 0.1 \mathrm{M}$ Tris Buffer ( $\mathrm{pH} 8)(50: 47: 3)$. The concentration of menaquinone- 4 was measured by HPLC equipped with a UV $(270 \mathrm{~nm})$ detector following separation of the analytes on an ODS column (Wakosil- 
II $5 \mathrm{C}_{18}-\mathrm{HG}$; Wako Pure Chemical Industries, Ltd.). The mobile phase consists of $\mathrm{EtOH} / \mathrm{MeOH} / 0.1 \mathrm{M}$ Tris Buffer (pH 8) $(50: 47: 3)$ at a flow rate of $1.0 \mathrm{ml} / \mathrm{min}$. The quantification range of menaquinone- 4 was $50 \mathrm{ng}$ to $100 \mu \mathrm{g} / \mathrm{m} l$ in plasma.

\section{Determination of tissue concentrations of radioactivity}

At 1.5, 24 and 168 hours after the 7th administration, the tissue concentrations of radioactivity were investigated using three male dogs at each time point. An additional male dog was treated at 864 hours in order to evaluate the unexcreted radioactivity level in the tissues. Dogs were anesthetized with pentobarbital (Nembutal $^{\circledR}$; Abbott Laboratories, North Chicago, IL , USA, $25 \mathrm{mg} / 0.5 \mathrm{ml} / \mathrm{kg} \mathrm{BW}$ ), cannulated at the carotid artery and then sacrificed by exsanguination. Tissues were collected as described previously ${ }^{11}$.

About 50 to $100 \mathrm{mg}$ of each tissue were weighed and incubated with $1 \mathrm{~m} l$ of Soluene- $350^{\circledR}$ overnight at room temperature. Bone tissues (except bone marrow) were solubilized with $1 \mathrm{ml}$ of $5 \mathrm{~N} \mathrm{HCl}$ and neutralized with 1 $\mathrm{m} l$ of $5 \mathrm{~N} \mathrm{KOH}$. A $100 \mu l$ aliquot of urine from the bladder and a $50 \mu l$ aliquot of bile from the gall bladder was solubilized with $1 \mathrm{~m} l$ of Soluene- $350^{\circledR}$. After solubilization, $15 \mathrm{ml}$ of scintillation fluid consisting of Insta-gel ${ }^{\boxplus /}$ $0.5 \mathrm{~N} \mathrm{HCl}(9: 1, \mathrm{v} / \mathrm{v})$ were added to each solubilized sample. Blood, plasma and erythrocyte samples were treated as described in Section 6 above.

Portions of the plasma, liver, kidney, spleen, adrenal and bile samples at 1.5 and 24 hours and adipose tissue and cancellous tissue samples at 1.5, 24 and 168 hours after the 7 th dosing were stored at $-20^{\circ} \mathrm{C}$ until the determination of the metabolic profile.

\section{Determination of radioactivity in urine and feces}

Four male dogs were housed in metabolic cages and urine and feces were collected daily during the repeated administration and up to 7 days after the 7 th administration.

Water was mixed with feces to make a total amount of $1500 \mathrm{~g}$. The mixture was homogenized and about 100 $\mathrm{mg}$ of the homogenates were incubated with $1 \mathrm{ml}$ Soluene- $350^{\circledR}$ overnight at room temperature. After solubilization, $15 \mathrm{~m} l$ of scintillation fluid comprising Insta-gel ${ }^{\oplus} / 0.5 \mathrm{~N} \mathrm{HCl}(9: 1, \mathrm{v} / \mathrm{v})$ were added to the solubilized samples. One hundred $\mu l$ urine samples were collected after recording the daily excreted volume. Cages were flushed with water to make $1000 \mathrm{~m} l$ and then a $100 \mu l$ sample was collected. Urine samples and the flushed samples were mixed with $15 \mathrm{~m} l$ of scintillation fluid consisting of Insta-gel ${ }^{\boxplus} / 0.5 \mathrm{~N} \mathrm{HCl}(9: 1, \mathrm{v} / \mathrm{v})$.

Urine samples 0-24 hours after the 1st and 7th dosings and fecal homogenate samples 0-24 hours after the 1st, 2nd and 7 th dosings were stored at $-20^{\circ} \mathrm{C}$ in order to determine the metabolic profiles.
10. Determination of the metabolic profiles in urine, feces, bile, plasma and tissues

One $\mathrm{m} l$ of plasma and approximately $1 \mathrm{~g}$ samples of liver, kidney, spleen and adrenal collected 1.5 and 24 hours after the 7th dosing and $1 \mathrm{~g}$ sample of adipose tissue and cancellous tissue of thighbone collected 1.5, 24 and 168 hours after the 7th dosing were extracted as described in a previous report.11,13) Fecal homogenates (about $1 \mathrm{~g}$ ) prepared from feces excreted within 24 hours after the 1st, 2 nd and 7 th dosings, $2 \mathrm{~m} l$ of urine excreted within 24 hours after the 1st and 7th dosings and bile 1.5 and 24 hours after the 7 th dosing were also treated as described previously ${ }^{11)}$.

Each pre-treated sample was subjected to TLC analysis under the following conditions: TLC plate; Kieselgel $60 \mathrm{~F}_{254}$ (Merck, Darmstadt, Germany), Developing solvent; Cyclohexane/Ether/Ethanol (16:4:3)

The TLC plates were placed in contact with an X-ray film (Ultrofilm; LKB, Bromma, Sweden) for 2 to 4 weeks to measure the radioactivity. After development (Acedol; Konica, Tokyo, Japan) and fixation (Acefix; Konica), each radioactive spot was scraped from the plate into glass vials and mixed with $12 \mathrm{ml}$ of a scintillation fluid (ACS-II; Amersham).

\section{Pharmacokinetic analysis}

Pharmacokinetic parameters were calculated from the plasma concentrations of radioactivity and unchanged menaquinone -4 by model independent analysis as described below.

$\mathrm{C}_{\max }$ and $\mathrm{T}_{\max }$ were determined from the measured concentrations. An $\mathrm{AUC}_{(0-24 \mathrm{hr})}$ was obtained from the plasma concentrations for 24 hours after each dosing using the trapezoidal method. The terminal half-life $\left(t_{1 / 2}\right)$ after the repeated administration was estimated from the slope of the terminal phase (from 72 hours onward) after the 7th (final) dosing. The $\mathrm{AUC}_{(0-\infty)}$ after the 7th dosing was then calculated using the trapezoidal method and the terminal $\mathrm{t}_{1 / 2}$. The $\mathrm{AUC}_{(0-\infty)}$ after the 1 st dosing was estimated as a sum of 24 hour value by the trapezoidal method and calculated value using the terminal $t_{1 / 2}$ value ( 80.1 hours) obtained in a previous single administration study ${ }^{11)}$.

\section{Results}

\section{Stability of $\left[{ }^{14} \mathrm{C}\right]$ menaquinone -4}

The radiochemical purity of the labeled compound based on the results of HPLC analysis was more than $99 \%$ for both the first and final doses. Thus, $\left[{ }^{14} \mathrm{C}\right] \mathrm{men}$ aquinone- 4 was considered to be stable at least for seven days in the dosing solution.

\section{Concentrations of radioactivity and unchanged menaquinone-4 in blood, plasma and erythro- cytes}

Fig. 2 shows the plasma concentrations of radioactivity during and after repeated oral administration of 




Fig. 2 Plasma concentrations of radioactivity in dogs during and after repeated oral administration of $\left[{ }^{14} \mathrm{C}\right]$ menaquinone -4 $(4 \mathrm{mg} / \mathrm{kg})$ once a day for seven days

Each point represents the mean \pm SEM of 4 animals.
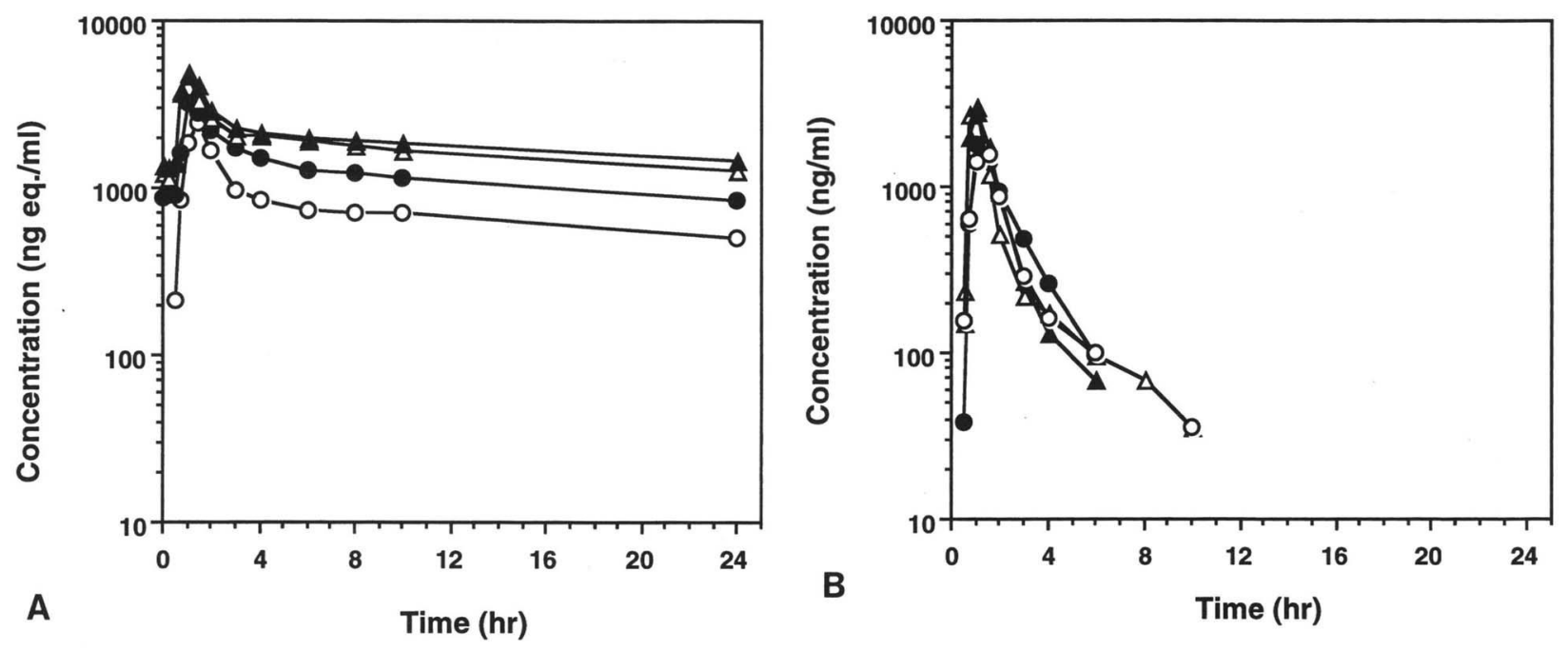

Fig. 3 Plasma concentration-time profiles of radioactivity and unchanged menaquinone- 4 for 24 hours after the 1 st, $3 \mathrm{rd}$, 5th and 7th dosings

Each point represents the mean of 4 animals.

Symbols represent the concentrations of radioactivity (A) and unchanged menaquinone-4 (B) after the 1st ( $-\bigcirc-)$, 3rd (- - ), 5th $(-\triangle-)$ and 7 th $(-\mathbf{\Delta}-)$ dosings, respectively.

$\left[{ }^{14} \mathrm{C}\right]$ menaquinone -4 to four male dogs at a dose of 4 $\mathrm{mg} / \mathrm{kg}$ once a day for seven days. The concentrations at 1.5, 4 and 24 hours after each dosing increased day by day and approached a steady state by the 7 th dose. The plasma concentrations of radioactivity decreased slowly after the final dosing. The $t_{1 / 2}$ value of the elimination from 72 to 168 hours after the 7 th dosing was 89.4 hours. Although higher radioactivity was found in plasma than in erythrocytes, the concentrations of radioactiv- ity in erythrocytes increased during repeated administration and did not reach a steady state by the 7 th dosing. The elimination of radioactivity from erythrocytes was fairly slow. The concentration 168 hours after the 7 th dosing decreased to one-fourth of that at 24 hours.

The plasma concentration-time profiles of radioactivity for 24 hours after the 1st, 3rd, 5th and 7th dosings and the corresponding profiles of unchanged menaquinone -4 are shown in Fig. 3A, B, respectively. The phar- 
Table I Pharmacokinetic parameters of radioactivity and unchanged menaquinone- 4 in dog plasma after the 1 st and 7 th dosings of $\left[{ }^{14} \mathrm{C}\right]$ menaquinone $-4(4 \mathrm{mg} / \mathrm{kg})$

\begin{tabular}{|c|c|c|c|c|}
\hline & $\begin{array}{l}\mathrm{T}_{\max } \\
(\mathrm{hr})\end{array}$ & $\begin{array}{c}\operatorname{mean} \mathrm{T}_{\max } \\
(\mathrm{hr})\end{array}$ & $\begin{array}{c}\mathrm{C}_{1.5 \mathrm{hr}} \\
\text { (ng eq. } / \mathrm{m} l \text { ) }\end{array}$ & $\begin{array}{c}\mathrm{C}_{24} \mathrm{hr} \\
\text { (ng eq./ml) }\end{array}$ \\
\hline \multicolumn{5}{|l|}{ 1st dosing } \\
\hline Radioactivity & $1-2$ & 1.5 & $2420.2 \pm 774.2$ & $497.5 \pm 107.9$ \\
\hline Unchanged Menaquinone 4 & $1-3$ & 1.5 & $1576.2 \pm 453.9$ & N.D. \\
\hline \multicolumn{5}{|l|}{ 7th dosing } \\
\hline Radioactivity & $0.75-1.5$ & 1 & $4148.6 \pm 577.0$ & $1442.9 \pm 232.5$ \\
\hline \multirow[t]{2}{*}{ Unchanged Menaquinone 4} & $0.75-1$ & 1 & $1703.6 \pm 271.2$ & N.D. \\
\hline & \multicolumn{2}{|l|}{$\begin{array}{c}\mathrm{AUC}_{(0-24 \mathrm{hr})} \\
\text { (ng eq. } \cdot \mathrm{hr} / \mathrm{m} l \text { ) }\end{array}$} & $\begin{array}{l}\text { terminal } \\
(\mathrm{hr})\end{array}$ & $\begin{array}{c}\operatorname{AUC}_{(0-\infty)} \\
\text { (ng eq. } \cdot \mathrm{hr} / \mathrm{m} l)\end{array}$ \\
\hline \multicolumn{5}{|l|}{ 1st dosing } \\
\hline Radioactivity & \multicolumn{2}{|l|}{$17680.3 \pm 4283.5$} & N.C. & $62915.1 \pm 12699.3^{*}$ \\
\hline Unchanged Menaquinone- 4 & \multicolumn{2}{|l|}{$3246.8 \pm 642.6$} & N.C. & N.C. \\
\hline \multicolumn{5}{|l|}{ 7th dosing } \\
\hline Radioactivity & $46170.0 \pm 5273.4$ & & $89.4 \pm 5.7$ & $184577.5 \pm 32373.6$ \\
\hline Unchanged Menaquinone- 4 & $3881.0 \pm 182.4$ & & N.C. & N.C. \\
\hline
\end{tabular}

mean $\mathrm{T}_{\max }: \mathrm{T}_{\max }$ for mean plasma concentration

$\mathrm{C}_{1.5} \mathrm{hr}$ : plasma concentration at 1.5 hours

$\mathrm{C}_{24 \mathrm{hr}}$ : plasma concentration at 24 hours

N.D. : not detected

N.C. : not calculated

* : calculated from $\mathrm{t}_{1 / 2}$ value (80.1 hours) in a single administration study ${ }^{11)}$

Each value for $\mathrm{C}_{1.5 \mathrm{hr}}, \mathrm{C}_{24 \mathrm{hr}}, \mathrm{AUC}_{(0-24 \mathrm{hr})}$, terminal $\mathrm{t}_{1 / 2}$ and $\mathrm{AUC}_{(0-\infty)}$ represents the mean $\pm \mathrm{SEM}$ of 4 animals.

macokinetic parameters calculated from the plasma concentrations of radioactivity and unchanged menaquinone -4 after the 1st and 7th dosings are presented in Table I..

The plasma concentrations of radioactivity after the 1st dosing reached maximum levels $\left(\mathrm{C}_{\max }\right)$ at 1 to 2 hours after dosing for individual animals (mean plasma concentrations of radioactivity reached a $\mathrm{C}_{\max }$ of 2420.2 ng eq. $/ \mathrm{m} l$ at 1.5 hours as shown in Fig. 3A and Table I), and thereafter decreased slowly. The plasma concentration of radioactivity increased day by day during repeated administration with similar time concentration profiles. The plasma concentrations at 1.5 (4148.6 ng eq. $/ \mathrm{m} l)$ and 24 hours (1442.9 $\mathrm{ng}$ eq. $/ \mathrm{ml}$ ) after the 7 th dosing were 1.7 and 2.9 times higher than those after the 1st dosing. The corresponding $\mathrm{AUC}_{(0-24 \mathrm{hr})}$ after the 7 th dosing $(46170.0 \mathrm{ng}$ eq. $\cdot \mathrm{hr} / \mathrm{m} l)$ was 2.6 times than that of the 1 st dosing ( $17680.3 \mathrm{ng}$ eq. $\cdot \mathrm{hr} / \mathrm{ml})$. For unchanged menaquinone -4 , however, constant plasma concentrations were observed during repeated administration, and the $\mathrm{AUC}_{(0-24 \mathrm{hr})}$ after the 7th dosing (3881.0 $\mathrm{ng} \cdot \mathrm{hr} / \mathrm{ml}$ ) was only 1.2 fold that of the 1 st dosing $(3246.8 \mathrm{ng} \cdot \mathrm{hr} / \mathrm{ml})$.

\section{Concentration of radioactivity in tissues}

The tissue concentrations of radioactivity 1.5, 24, 168 and 864 hours after the 7th dosing are shown in Table II. The concentrations in blood, plasma and erythrocyte at the corresponding time are also shown.

At 1.5 hours after the 7th administration, bile in the gall bladder showed the highest concentration of radioactivity (112987.1 ng eq. $/ \mathrm{m} l$ ), followed by the liver (28404.2 ng eq./g), adipose tissue (26318.3 ng eq./g), gall bladder (14847.5 $\mathrm{ng}$ eq./g) and spleen (14542.1 ng eq./g). The levels in these tissues were much higher than in other tissues and plasma (3511.6 $\mathrm{ng}$ eq. $/ \mathrm{m} l$ ), and were 1.0, 0.9, 10.1, 0.6 and 1.2 times higher, respectively, than the corresponding concentrations after a single administration ${ }^{11)}$. At 24 hours after the 7 th dosing, radioactivity levels in all tissues except liver and spleen were similar to those at 1.5 hours. The radioactivity levels in the liver and spleen decreased together with a decrease in the levels in plasma. The radioactivity concentrations in tissues generally decreased by 168 hours, while those in adipose tissue and bile remained relatively higher levels than in other tissues. The concentrations in erythrocytes at 168 hours still kept similar level to a low level observed at 24 hours. At 864 hours (36 days), the concentrations in adipose and bile decreased to one-sixth and one-fifth, respectively, of those at 168 hours.

In bone tissues at 1.5 hours after the 7 th administration, the bone marrow ( $9516.8 \mathrm{ng}$ eq./g) of ribs, and cancellous tissue (6376.5 ng eq./g) and marrow (5261.1 ng eq. $/ g$ ) of thighbone showed higher concentrations than plasma (3511.6 ng eq. $/ \mathrm{m} l$ ). The concentrations in these 
Table II Concentrations of radioactivity in tissues of dogs at 1.5, 24, 168 and 864 hours after repeated oral administration of $\left[{ }^{14} \mathrm{C}\right]$ menaquinone $-4(4 \mathrm{mg} / \mathrm{kg})$ once a day for seven days

\begin{tabular}{|c|c|c|c|c|c|c|c|}
\hline \multirow{3}{*}{ Tissue } & \multicolumn{7}{|c|}{ Time after the 7 th dosing } \\
\hline & \multicolumn{2}{|c|}{$1.5 \mathrm{hr}$} & \multicolumn{2}{|c|}{$24 \mathrm{hr}$} & \multicolumn{2}{|c|}{$168 \mathrm{hr}$} & \multirow{2}{*}{$\begin{array}{r}864 \mathrm{hr}^{*} \\
90.5\end{array}$} \\
\hline & 441.1 & (144.6) & 401.1 & $(154.2)$ & 383.6 & $(104.8)$ & \\
\hline Cerebellum & 445.1 & $(107.6)$ & 442.5 & $(211.1)$ & 359.6 & (101.1) & 87.1 \\
\hline Hypophysis & 1593.9 & $(498.3)$ & 1194.8 & $(245.0)$ & 617.8 & (153.4) & 96.2 \\
\hline Spinal cord & 238.8 & $(52.1)$ & 190.1 & $(76.7)$ & 170.8 & $(49.8)$ & 71.1 \\
\hline \multicolumn{8}{|l|}{ Eye } \\
\hline Aqueous humor & 36.9 & $(11.0)$ & 32.1 & $(10.9)$ & 7.2 & $(3.7)$ & N.D. \\
\hline Cornea & 234.1 & $(50.5)$ & 151.5 & $(48.6)$ & 144.3 & $(41.2)$ & 26.8 \\
\hline Lens & 59.7 & $(23.4)$ & 40.5 & $(9.5)$ & 81.9 & $(12.1)$ & 30.3 \\
\hline Iris & 113.0 & $(31.0)$ & 82.6 & $(43.9)$ & \multicolumn{2}{|c|}{ N.D. } & N.D. \\
\hline Ciliary body & 616.1 & (93.1) & 213.5 & $(34.8)$ & \multicolumn{2}{|c|}{$274.7 \quad(72.2)$} & N.D. \\
\hline Vitreous body & 37.6 & (10.7) & 32.7 & (12.6) & \multicolumn{2}{|c|}{ N.D. } & N.D. \\
\hline Choroidea & 228.2 & (13.5) & 134.7 & (18.7) & 66.4 & (28.0) & N.D. \\
\hline Retina & 365.6 & $(60.8)$ & 221.6 & $(50.4)$ & 223.7 & $(59.3)$ & 48.0 \\
\hline Sclera & 178.9 & (13.3) & 141.7 & $(6.9)$ & 77.3 & (17.3) & 40.0 \\
\hline Optic nerve & 315.5 & $(63.9)$ & 174.6 & $(92.1)$ & 266.4 & $(79.8)$ & 109.9 \\
\hline Submaxillary gland & 1846.5 & $(266.5)$ & 1462.4 & $(478.4)$ & 612.6 & (139.1) & 63.9 \\
\hline Lymph node & 1239.4 & (118.1) & 1068.9 & $(253.5)$ & 587.2 & (136.6) & 102.4 \\
\hline Trachea & 320.0 & $(24.2)$ & 321.2 & $(39.5)$ & 173.0 & $(60.9)$ & 35.4 \\
\hline Thyroid & 1386.3 & $(241.8)$ & 1220.7 & $(378.1)$ & 713.5 & $(202.6)$ & 158.4 \\
\hline Thymus & 2359.0 & $(223.1)$ & 2567.7 & $(99.0)$ & 1198.4 & $(558.5)$ & 641.4 \\
\hline Heart & 2003.8 & $(360.0)$ & 1221.3 & (134.2) & 501.5 & (104.6) & 80.1 \\
\hline Lung & 2091.5 & $(212.7)$ & 941.7 & $(165.1)$ & 463.3 & (127.7) & 61.8 \\
\hline Adipose & 26318.3 & $(6562.1)$ & 30766.3 & 11357.9) & 20733.3 & $(2252.2)$ & 3637.8 \\
\hline Spleen & 14542.1 & (4563.5) & 934.7 & $(272.3)$ & 548.3 & $(146.7)$ & 95.0 \\
\hline Pancreas & 2303.9 & $(247.5)$ & 1705.6 & (436.5) & 912.8 & $(235.2)$ & 137.8 \\
\hline Adrenal & 5642.1 & $(866.5)$ & 3704.9 & $(908.2)$ & 3424.7 & (849.1) & 785.2 \\
\hline \multicolumn{8}{|l|}{ Kidney } \\
\hline cortex & 2713.6 & $(343.0)$ & 1696.8 & $(408.6)$ & 831.4 & (195.4) & 124.9 \\
\hline medulla & 1762.5 & $(34.9)$ & 1011.2 & (193.2) & 358.4 & $(98.7)$ & 46.1 \\
\hline Muscle & 933.8 & $(85.1)$ & 754.1 & (188.8) & 364.4 & $(106.6)$ & 98.8 \\
\hline Sciatic nerve & 2845.8 & (1164.8) & 1155.7 & $(71.2)$ & 971.6 & $(303.1)$ & 531.9 \\
\hline Testis & 777.5 & (90.3) & 747.5 & $(208.9)$ & 569.1 & (114.9) & 84.6 \\
\hline Prostate gland & 1432.0 & $(268.7)$ & 1096.2 & $(288.6)$ & 630.4 & (110.9) & 74.7 \\
\hline Urinary bladder & 830.8 & (133.2) & 761.9 & (163.6) & 447.1 & (105.5) & 138.5 \\
\hline Urine & 4251.2 & (1085.6) & 5183.9 & (1495.6) & 193.2 & $(42.0)$ & 27.2 \\
\hline Aorta & 600.3 & (82.3) & 427.2 & (99.2) & 359.0 & $(70.8)$ & 86.8 \\
\hline Vein & 1235.3 & (146.3) & 933.3 & $(272.2)$ & 902.5 & (411.5) & 28.3 \\
\hline Skin & 1644.9 & $(444.5)$ & 2334.2 & $(666.9)$ & 1419.2 & (374.3) & 164.0 \\
\hline Liver & 28404.2 & (6842.5) & 4349.0 & $(84.8)$ & 2054.3 & $(617.9)$ & 191.0 \\
\hline Gall bladder & 14847.5 & $(5737.0)$ & 6760.0 & (3596.5) & 824.4 & $(203.9)$ & 36.6 \\
\hline Bile & 112987.1 & (19105.6) & 97542.4 & 23747.3) & 8019.4 & (2122.9) & 1716.4 \\
\hline Stomach & 1411.4 & $(156.4)$ & 904.1 & $(59.6)$ & 411.3 & (73.5) & 49.5 \\
\hline Duodenum & 8963.0 & $(865.9)$ & 1394.9 & $(221.4)$ & 352.0 & $(84.2)$ & 59.5 \\
\hline Jejunum & 6699.7 & $(606.7)$ & 1679.9 & $(414.5)$ & 451.9 & (111.8) & 59.3 \\
\hline Ileum & 1337.1 & (164.8) & 1786.8 & $(485.9)$ & 399.6 & $(59.9)$ & 59.6 \\
\hline Caecum & 1305.7 & $(81.6)$ & 2810.6 & (1045.9) & 327.1 & $(39.2)$ & 46.2 \\
\hline Large intestine & 1036.1 & $(243.9)$ & 1940.0 & $(627.5)$ & 327.1 & $(37.4)$ & 88.5 \\
\hline \multicolumn{8}{|l|}{ Bone } \\
\hline Parietal bone & 53.9 & $(9.6)$ & 60.4 & $(7.7)$ & 56.0 & $(8.5)$ & 40.6 \\
\hline Ribs & 267.8 & $(48.8)$ & 246.5 & $(38.9)$ & 185.7 & $(33.6)$ & 112.0 \\
\hline Bone marrow & 9516.8 & (1440.6) & 4862.9 & $(494.4)$ & 883.8 & (120.7) & 321.6 \\
\hline Ilium & 533.3 & (29.9) & 239.0 & $(20.8)$ & 148.8 & (19.8) & 172.5 \\
\hline \multicolumn{8}{|l|}{ Thighbone } \\
\hline Diaphysis & 106.8 & (33.9) & 96.8 & (11.0) & 43.5 & $(8.0)$ & 42.4 \\
\hline Metaphysis & 224.3 & (39.3) & 150.3 & $(38.5)$ & 91.3 & $(31.0)$ & 52.2 \\
\hline Cancellous tissue & 6376.5 & (1549.4) & 3899.6 & $(418.2)$ & 944.9 & $(225.8)$ & 221.3 \\
\hline Bone marrow & 5261.1 & (1504.5) & 3508.9 & $(459.5)$ & 1688.8 & $(330.8)$ & 506.9 \\
\hline Blood & 2207.3 & $(62.8)$ & 1137.8 & $(226.1)$ & 437.2 & (118.3) & 131.8 \\
\hline Plasma & 3511.6 & (167.8) & 1804.0 & $(222.7)$ & 377.8 & (101.3) & 42.3 \\
\hline Erythrocyte & 496.5 & $(72.5)$ & 408.8 & $(66.7)$ & 401.4 & $(109.8)$ & 275.8 \\
\hline
\end{tabular}

N.D. : Not detected

Each value represents the mean $( \pm \operatorname{SEM})$ of 3 animals $(*: n=1)$. 
Table III Cumulative excretion of radioactivity in urine and feces of dogs during and up to 7 days after repeated oral administration of $\left[{ }^{14} \mathrm{C}\right]$ menaquinone $-4(4 \mathrm{mg} / \mathrm{kg})$ once a day for seven days

\begin{tabular}{rllll}
\hline \multicolumn{2}{c}{ Time } & Urine & Feces & Total \\
\hline 1st dose & $0-24 \mathrm{hr}$ & $1.3 \pm 0.2$ & $31.4 \pm 10.8$ & $32.7 \pm 10.8$ \\
2nd dose & $0-24 \mathrm{hr}$ & $1.4 \pm 0.2$ & $54.3 \pm 7.0$ & $55.7 \pm 7.1$ \\
3rt dose & $0-24 \mathrm{hr}$ & $1.7 \pm 0.2$ & $77.9 \pm 3.2$ & $79.6 \pm 3.2$ \\
4th dose & $0-24 \mathrm{hr}$ & $1.6 \pm 0.2$ & $75.7 \pm 3.8$ & $77.3 \pm 3.7$ \\
5th dose & $0-24 \mathrm{hr}$ & $1.9 \pm 0.2$ & $77.3 \pm 2.8$ & $79.2 \pm 2.8$ \\
6th dose & $0-24 \mathrm{hr}$ & $2.0 \pm 0.2$ & $78.4 \pm 2.6$ & $80.4 \pm 2.6$ \\
7th dose & $0-24 \mathrm{hr}$ & $2.0 \pm 0.2$ & $81.1 \pm 2.8$ & $83.1 \pm 2.8$ \\
& $-48 \mathrm{hr}$ & $2.2 \pm 0.2$ & $82.6 \pm 2.7$ & $84.8 \pm 2.7$ \\
& $-72 \mathrm{hr}$ & $2.3 \pm 0.2$ & $83.0 \pm 2.7$ & $85.3 \pm 2.7$ \\
& $-96 \mathrm{hr}$ & $2.3 \pm 0.2$ & $83.3 \pm 2.7$ & $85.6 \pm 2.7$ \\
& $-120 \mathrm{hr}$ & $2.3 \pm 0.2$ & $83.6 \pm 2.7$ & $85.9 \pm 2.7$ \\
& $-144 \mathrm{hr}$ & $2.4 \pm 0.2$ & $83.8 \pm 2.7$ & $86.2 \pm 2.7$ \\
\hline
\end{tabular}

*: The values were calculated for a definite period by the following equation. Excretion rate $(\%)=$ (cumulative excretion amounts/cumulative doses) $\times 100$

Each value represents the mean \pm SEM of 4 animals.

tissues were 2.7, 2.6 and 3.7 fold greater than those at corresponding time after a single administration, although that in plasma increased only 1.2 fold. The concentrations in these bone tissues decreased gradually, becoming 2 to 3 times greater than plasma at 24 hours and 2 to 4 times greater at 168 hours.

\section{Excretion of radioactivity in urine and feces}

The daily excretion of radioactivity in urine and feces during repeated oral administration and up to 7 days after final dosing is shown in Table III. The excretions of radioactivity in urine and feces were $2.4 \%$ and $84.0 \%$ (combined total of $86.3 \%$ ) within 168 hours after the 7 th (final) dose. The majority of the radioactivity was excreted in the feces, as was the case for the single administration study ${ }^{11)}$.

\section{Metabolic profiles in urine, feces, bile, plasma and tissues}

The relative values of metabolites in plasma, urine, feces, bile, liver, kidney, spleen, adipose, adrenal and cancellous tissue of thighbone after seven repeated administration are shown in Table IV. A majority of the radioactivity in feces excreted within 24 hours after the 7 th dosing was unchanged menaquinone-4 (35.5\%), and the level was comparable to those after the 1st and 2nd dosings. Most of the radioactivity in urine and bile at each collection time was present in the origin fraction on TLC.

Unchanged menaquinone- 4 was the main form in plasma $(43.1 \%)$, liver $(54.2 \%)$, kidney $(36.6 \%)$, spleen $(57.5 \%)$ and adrenal $(16.1 \%)$ at 1.5 hours after the 7 th dosing. The metabolites, $\omega-\mathrm{COOH}, \mathrm{K}$ acid $\mathrm{I}$ and $\mathrm{K}$ acid II, were observed in these tissues at 1.5 hours. The rela- tive amount of unchanged menaquinone -4 decreased at 24 hours while those of the three metabolites increased. Unchanged menaquinone- 4 was the main form in adipose tissue at 1.5, 24 and 168 hours after the 7 th dosing, with the relative amounts being $94.5,97.0$ and $98.2 \%$, respectively.

In the cancellous tissue of thighbone at 1.5 hours after the 7 th dosing, $47.8 \%$ of the radioactivity was unchanged menaquinone- 4 . The relative amounts of unchanged menaquinone -4 at 24 and 168 hours increased to 52.7 and $66.4 \%$, respectively.

The results of the present repeated administration study were almost the same as those of an earlier single administration study ${ }^{11)}$.

\section{Discussion}

$\left[{ }^{14} \mathrm{C}\right]$ menaquinone -4 was administered orally to male dogs at a dose of $4 \mathrm{mg} / \mathrm{kg}$ once a day for 7 days and the absorption, distribution, metabolism and excretion of the compound were investigated. The results were compared with those of a single administration study in $\operatorname{dog} s^{11)}$ in order to examine the effects of repeated dosing on the metabolic fate of the drug.

The mean plasma concentrations of both the radioactivity and unchanged menaquinone -4 reached maximum levels within 1.5 hours after the 1st, 3rd, 5th and 7 th administrations (Fig. 3A, B, Table I), indicating that $\left[{ }^{14} \mathrm{C}\right]$ menaquinone -4 is absorbed rapidly and constantly during repeated administration. The plasma concentrations of radioactivity approached a steady state by the 7 th administration, while the concentration of radioactivity in erythrocytes increased as the number of dosing times increased. The concentrations in erythrocytes were, however, lower than those in plasma and 
Table IV Relative values of metabolites in urine, feces and tissues of dogs during and after repeated oral administration of [ $\left[{ }^{14} \mathrm{C}\right]$ menaquinone-4 $(4 \mathrm{mg} / \mathrm{kg})$ once a day for seven days

Liver

\begin{tabular}{lrr}
\hline & \multicolumn{2}{c}{ Time (hr) } \\
\cline { 2 - 3 } & \multicolumn{1}{c}{1.5} & \multicolumn{1}{c}{24} \\
\hline MK-4 & $54.2 \pm 3.2$ & $12.6 \pm 2.7$ \\
$\omega-\mathrm{COOH}$ & $5.5 \pm 1.4$ & $3.0 \pm 0.2$ \\
$\mathrm{~K}$ acid I and II & $1.4 \pm 0.2$ & $4.9 \pm 0.6$ \\
Origin & $27.7 \pm 4.2$ & $53.9 \pm 4.8$ \\
\hline
\end{tabular}

\begin{tabular}{|c|c|c|}
\hline \multicolumn{3}{|l|}{ Kidney } \\
\hline & \multicolumn{2}{|c|}{ Time (hr) } \\
\hline & 1.5 & 24 \\
\hline $\mathrm{MK}-4$ & $36.6 \pm 5.2$ & $30.2 \pm 4.7$ \\
\hline$\omega-\mathrm{COOH}$ & $9.3 \pm 2.2$ & $5.6 \pm 0.6$ \\
\hline $\mathrm{K}$ acid $\mathrm{I}$ and II & $1.2 \pm 1.2$ & $2.3 \pm 1.1$ \\
\hline Origin & $38.4 \pm 2.2$ & $41.9 \pm 1.7$ \\
\hline
\end{tabular}

Spleen

\begin{tabular}{lrr}
\hline & \multicolumn{2}{c}{ Time (hr) } \\
\cline { 2 - 3 } & \multicolumn{1}{c}{1.5} & \multicolumn{1}{c}{24} \\
\hline MK-4 & $57.5 \pm 3.5$ & $24.9 \pm 6.5$ \\
$\omega-\mathrm{COOH}$ & $9.8 \pm 3.1$ & $14.2 \pm 1.8$ \\
$\mathrm{~K}$ acid I and II & $3.6 \pm 0.7$ & $3.7 \pm 3.7$ \\
Origin & $4.6 \pm 1.0$ & $31.1 \pm 7.0$
\end{tabular}

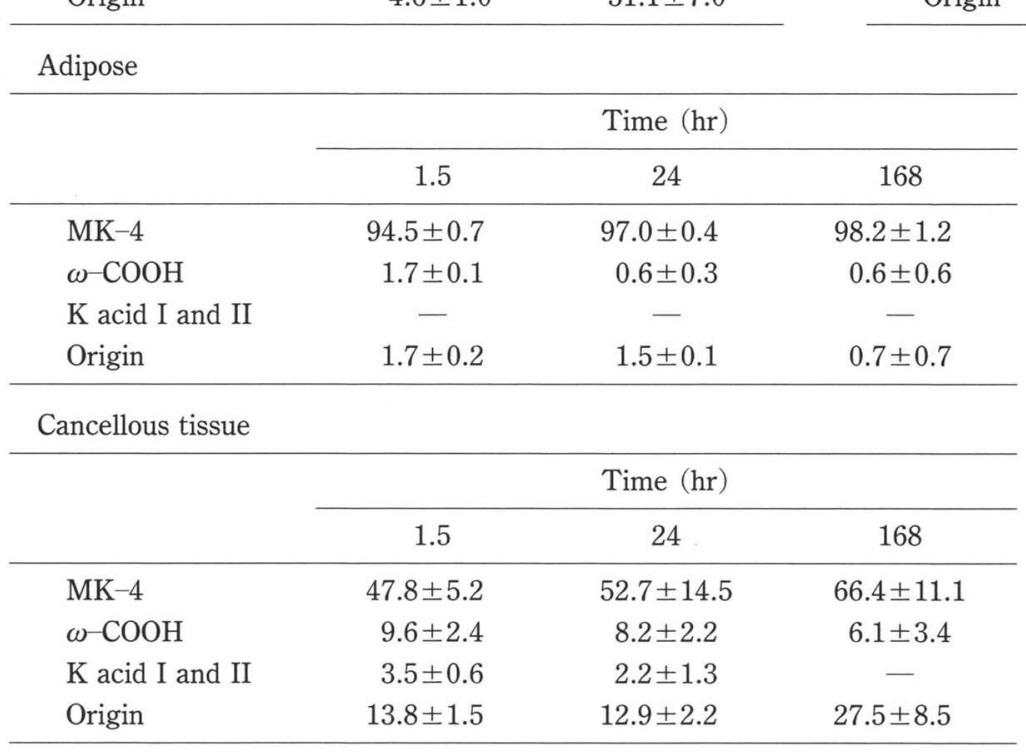

Urine, Feces
Adrenal

\begin{tabular}{|c|c|c|}
\hline & \multicolumn{2}{|c|}{ Time (hr) } \\
\hline & 1.5 & 24 \\
\hline MK-4 & $16.1 \pm 0.5$ & $19.0 \pm 2.3$ \\
\hline$\omega-\mathrm{COOH}$ & $6.0 \pm 3.2$ & $9.4 \pm 1.4$ \\
\hline $\mathrm{K}$ acid $\mathrm{I}$ and II & - & - \\
\hline Origin & $40.6 \pm 3.4$ & $35.5 \pm 4.2$ \\
\hline \multicolumn{3}{|l|}{ Plasma } \\
\hline & \multicolumn{2}{|c|}{ Time $(h r)$} \\
\hline & 1.5 & 24 \\
\hline $\mathrm{MK}-4$ & $43.1 \pm 3.5$ & $10.3 \pm 4.8$ \\
\hline$\omega-\mathrm{COOH}$ & $2.1 \pm 0.2$ & - \\
\hline $\mathrm{K}$ acid $\mathrm{I}$ and $\mathrm{II}$ & $12.7 \pm 1.5$ & $19.4 \pm 2.2$ \\
\hline Origin & $29.7 \pm 3.1$ & $59.4 \pm 3.2$ \\
\hline \multicolumn{3}{|l|}{ Bile } \\
\hline & \multicolumn{2}{|c|}{ Time (hr) } \\
\hline & 1.5 & 24 \\
\hline $\mathrm{MK}-4$ & $1.0 \pm 0.2$ & $0.8 \pm 0.4$ \\
\hline$\omega-\mathrm{COOH}$ & $4.0 \pm 0.5$ & $1.3 \pm 0.1$ \\
\hline $\mathrm{K}$ acid I and II & $4.9 \pm 0.9$ & $5.3 \pm 0.5$ \\
\hline Origin & $71.8 \pm 1.1$ & $77.7 \pm 1.0$ \\
\hline
\end{tabular}

\begin{tabular}{lrrrrrr}
\hline & \multicolumn{3}{c}{ Feces } & & \multicolumn{2}{c}{ Urine } \\
\cline { 2 - 3 } \cline { 6 - 6 } & 1st $(0-24 \mathrm{hr})$ & 2nd $(0-24 \mathrm{hr})$ & $7 \operatorname{th}(0-24 \mathrm{hr})$ & & 1 st $(0-24 \mathrm{hr})$ & $7 \operatorname{th}(0-24 \mathrm{hr})$ \\
\hline MK-4 & $45.5 \pm 3.4$ & $44.0 \pm 4.4$ & $35.5 \pm 3.1$ & & - & - \\
$\omega$ COOH & $7.5 \pm 0.1$ & $8.8 \pm 0.8$ & $12.5 \pm 0.9$ & & - & - \\
K acid I and II & $4.5 \pm 0.8$ & $3.2 \pm 0.3$ & $5.0 \pm 0.2$ & & $1.7 \pm 1.0$ & $6.5 \pm 2.5$ \\
Origin & $12.4 \pm 1.9$ & $18.8 \pm 3.3$ & $19.2 \pm 2.3$ & & $98.3 \pm 1.0$ & $88.5 \pm 2.1$ \\
\hline
\end{tabular}

(\% in extracted sample)

MK-4 : menaquinone-4

Each value represents the mean \pm SEM of 3 animals. 
decreased slowly after the final dosing (Table II). It has not been reported in toxicity studies to date ${ }^{14)}$ that serious side-effects might occur based on the accumulation of the drug in erythrocytes. The elimination half-life of the radioactivity concentration in plasma (89.4 hours) was almost the same as that in a single dosing study (80.1 hours) ${ }^{11)}$, and the plasma concentration profile of unchanged menaquinone- 4 was almost same after each dosing. These results suggest that repeated administration does not affect the clearance of menaquinone-4 from plasma in dogs.

A majority (84.0\%) of the radioactivity was excreted in the feces by 168 hours after the 7th dosing (Table III), as was observed in the single administration study ${ }^{11)}$. The bile contained fairly high concentrations of radioactivity at each time point (Table II). These results support that $\left[{ }^{14} \mathrm{C}\right]$ menaquinone -4 may be mainly excreted in the feces via biliary excretion. As shown in Table III, around $14 \%$ of the radioactivity had not been recovered by 168 hours (final collection). It is believed, based on the concentration in tissues (Table II), that unrecovered radioactivity still remains in the adipose and other tissues at 168 hours and decreases at an extremely slow rate. Table $\mathbf{V}$ shows the estimated amounts of radioactivity in adipose, muscle, skin and liver calculated using both the radioactivity concentrations at 168 hours and tissue weight which was obtained from either actual weight or the theoretical value previously reported $^{15)}$. Total radioactivity still remained in adipose, muscle, skin and liver 168 hours after final dosing $(12.2 \%$ in total) correspond well with the unrecovered amount of radioactivity in feces and urine (Table III).

At 1.5 hours after the 7 th administration the bile, liver, gall bladder and spleen showed much higher levels of radioactivity than other tissues and plasma (Table II), and the levels were comparable to the results of the single administration study ${ }^{11)}$. The highest concentration of radioactivity was found in the adipose tissue as mainly unchanged menaquinone -4 . The concentration at 864 hours was one-sixth that at 168 hours. These findings suggest that excess menaquinone- 4 is stored temporarily in the adipose tissue, then will be gradually released into the systemic circulation.

The elimination of radioactivity from other tissues was also slow in comparison with that from plasma and liver. The TLC analysis (Table IV) demonstrated that the metabolic profile in the tissues was similar to that after a single dosing ${ }^{11)}$, indicating that repeated administration does not affect the metabolism of menaquinone4.

The radioactivity levels in the marrow and cancellous tissue of thighbone and the marrow of ribs after the 7th administration were $5261.1-9516.8 \mathrm{ng}$ eq. $/ \mathrm{g}$ (ca $1.2-$ $2.1 \times 10^{-5} \mathrm{M}$ ) and $3508.9-4862.9 \mathrm{ng}$ eq. $/ \mathrm{g}$ (ca $0.8-1.1 \times$ $10^{-5} \mathrm{M}$ ) at 1.5 and 24 hours, respectively. These levels were 1.5 to 2.7 times higher than those in plasma. The concentrations in these three tissues at 1.5 hours were
Table V Radioactivity remaining in tissues of dogs at 168 hours after repeated oral administration of $\left[{ }^{14} \mathrm{C}\right]$ menaquinone- $4(4 \mathrm{mg} / \mathrm{kg})$ once a day for seven days

\begin{tabular}{lc}
\hline Tissue & Amount $(\%$ of dose $)$ \\
\hline Adipose & $10.7 \pm 1.2^{\mathrm{a})}$ \\
Muscle & $0.6 \pm 0.2^{\mathrm{a})}$ \\
Skin & $0.7 \pm 0.2^{\mathrm{a})}$ \\
Liver & $0.2 \pm 0.0^{\mathrm{b})}$ \\
\hline
\end{tabular}

a) : calculated from the radioactivity concentration at 168 hours and the theoretical tissue weight ${ }^{15)}$

b) : calculated from the radioactivity concentration at 168 hours and the actual tissue weight

Each value represents the mean \pm SEM of 3 animals.

3.7, 2.6 and 2.7 fold higher than those observed in the single dose study ${ }^{11}$, while only 1.2 times higher for plasma. The TLC analysis for the metabolic profile study revealed that a majority ( 47.8 to $66.4 \%$ ) of the radioactivity in the cancellous tissue up to 168 hours corresponded to unchanged menaquinone -4 . These results suggest that menaquinone -4 administered repeatedly accumulated to particularly high levels in bone tissues and that these levels were comparable to the pharmacologically effective concentrations of menaquinone- $4\left(10^{-6}-10^{-5}\right.$ M) observed in in vitro study on bone formation ${ }^{2)}$. This is fully consistent with the recent study in ovariectomized rats ${ }^{10)}$ in which $\left[{ }^{14} \mathrm{C}\right]$ menaquinone- 4 was distributed to and accumulated in bone tissues after repeated oral administration of $\left[{ }^{14} \mathrm{C}\right]$ menaquinone -4 once a day for ten days. Recent studies in rats ${ }^{16,17)}$ demonstrated that orally administered phylloquinone (vitamin $\mathrm{K}_{1}$ ) distributes in nonhepatic tissues, including bone, as not only phylloquinone but also menaquinone-4. It can be proposed from these results that menaquinone -4 rather than phylloquinone is an active form of the vitamin $\mathrm{K}$ family in vivo.

It has been shown in recent reports ${ }^{18,19)}$ that circulating levels of vitamin $\mathrm{K}$ are related to bone fractures in humans. In the present study, we demonstrated that menaquinone- 4 in bone tissues more than in plasma accumulated by repeated administration. This suggests the possibility that the vitamin $\mathrm{K}$ concentration in bone tissues may be closely related to bone fractures and bone-related diseases such as osteoporosis. We are also investigating the effects of menaquinone- 4 on bone metabolism following its distribution to the tissue.

In conclusion, the plasma concentration of radioactivity in dogs increased due to repeated administration of $\left[{ }^{14} \mathrm{C}\right]$ menaquinone -4 once a day for seven days, and the compound accumulated especially in adipose and bone tissues. The concentrations in bone tissues maintained the pharmacologically effective levels for an extended period of time. It is thus expected that the repeated administration of menaquinone- 4 may contribute to the therapeutic treatment of osteoporosis. 
Acknowledgments: The authors wish to thank Dr. Tadashi Sato for his support during this study.

\section{References}

1) Orimo, H., Fujita, T., Onomura, T., Inoue, T., Kushida, K., and Shiraki, M.: Clinical evaluation of Ea-0167 (Menatetrenone) in the treatment of osteoporosis: Phase III double-blind multicenter comparative study with Alfacalcidol. Clin. Eval., 20: 45-100 (1992).

2) Koshihara, Y., Hoshi, K., and Shiraki, M.: Enhancement of mineralization of human osteoblasts by Vitamin $\mathrm{K}_{2}$ (menaquinone 4). J. Clin. Exp. Med., 161: 439-440 (1992).

3) Akiyama, Y., Hara, K., Ohkawa, I., and Tajima, T.: Effects of Menatetrenone on bone loss induced by ovariectomy in rats. Japan J. Pharmacol., 62: 145-153 (1993).

4) Kinoshita, K., Katayama, K., Horie, H., Matsuura, T., Takamatsu, T., Tsutsumi, J., Yamato, C., Fujita, T., Miyao, K., Baba, S., and Konishi, T.: Studies on metabolism of menaquinone-4. I. Absorption, tissue distribution, excretion in rats and guinea-pigs. Oyo YakuriPharmacometrics, 5: 505-515 (1971).

5) Hirate, J., Horikoshi, I., Watanabe, J., Tadano, K., Yamato, C., and Fujita, T.: Disposition of menaquinone- 4 following intravenous and oral administration to rats. Oyo Yakuri-Pharmacometrics, 29: 775-781 (1985).

6) Tadano, K., Yuzuriha, T., and Miyake, Y.: The placental and mammary transport of $\left[{ }^{14} \mathrm{C}\right]$ menaquinone -4 in rats. $J$. Nutr. Sci. Vitaminol., 35: 393-405 (1989).

7) Tadano, K., Yuzuriha T., Ikeuchi, T., Sato, T., and Fujita, T.: Effect of solubilizer on the metabolic fate of menaquinone-4 in rats. J. Pharmacobio-Dyn., 12: 646-651 (1989).

8) Sano, Y., Tadano, K., Kikuchi, K., Kaneko, K., and Yuzuriha, T.: Pharmacokinetic characterization of menaquinone- 4 in dogs by sensitive HPLC determination. J. Nutr. Sci. Vitaminol., 39: 555-566 (1993).

9) Sano, Y., Tadano, K., Kaneko, K., Kikuchi, K., and Yuzuriha, T.: Metabolic fate of menatetrenone in rats -absorption, distribution, metabolism and excretion after a single oral administration-. Jpn. Pharmacol. Ther., 23: 207(2659)-215(2667) (1995).

10) Sano, Y., Tadano, K., Kaneko, K., Kikuchi, K., and Yu- zuriha, T.: Distribution of menaquinone-4, a therapeutic agent for osteoporosis, in bone and other tissues of rats. J. Nutr. Sci. Vitaminol., 41: 499-514 (1995).

11) Sano, Y., Tadano, K., Kaneko, K., Kikuchi, K., and Yuzuriha, T.: Metabolic fate of menatetrenone in dogs (I)absorption, distribution, metabolism and excretion after a single oral administration-. Xenobio. Metabol. and Dispos., 12(1): 48-57 (1997).

12) Shimada, K., Tadano, K., Satoh, T., Hashimoto, K., Tanaka, S., and Yuzuriha, T.: Synthesis of all trans [ $3^{\prime}$ $\left.{ }^{14} \mathrm{C}\right]$ menaquinone-4. J. Labelled Compounds and Radiopharmaceuticals., 27: 1293-1298 (1989).

13) Tadano, K., Yuzuriha, T., Sato, T., Fujita, T., Shimada, K., Hashimoto, K., and Satoh, T.: Identification of menaquinone-4 metabolites in the rat. J. Pharmacobio-Dyn., 12: 640645 (1989).

14) Goldsmith, L.A., Keller, J.G., Noguchi, M., Matsubara, Y. and Sagami, F.: 3-Month oral (capsule) toxicity study with 1-month reversibility period in dogs with Menatetrenone. Jpn. Pharmacol. Ther., 23: 157(2609)-170(2622) (1995).

15) Sawada, Y.: in Applied Pharmacokinetics-Theory and Experiments-, Hanano, M., Umemura, K., and Iga, T. (eds), Tokyo; Soft Science, Inc., pp 477 (1985).

16) Thijssen, H.H.W. and Drittij-Reijnders, M.J.: Vitamin K distribution in rat tissues: Dietary phylloquinone is a source of tissue menaquinone-4. Br. J. Nutr., 72: 415-425 (1994).

17) Thijssen, H.H.W., Drittij-Reijnders, M.J. and Fischer, M.A.J.G.: Phylloquinone and menaquinone- 4 distribution in rats: Synthesis rather than uptake determines menaquinone-4 organ concentrations. J. Nutr., 126: 537-543 (1996).

18) Hodges, S.J., Akesson, K., Vergnaud, P., Obrant, K. and Delmas, P.D.: Circulating levels of vitamin $\mathrm{K}_{1}$ and $\mathrm{K}_{2}$ decreased in elderly women with hip fracture. J. Bone Miner. Res., 8: 1241-1245 (1993).

19) Roberts, N.B., Holding, J.D., Walsh, H.P.J., Klenerman, L., Helliwell, T., King, D. and Shearer, M.: Serial changes in serum vitamin $\mathrm{K}_{1}$, triglyceride, cholesterol, osteocalcin and 25-hydroxyvitamin $\mathrm{D}_{3}$ in patients after hip replacement for fractured neck of femur or osteoarthritis. Eur. J. Clin. Invest., 26: 24-29 (1996). 